Michel Cahen's Review of A Short History of Mozambique: Some Thoughts

Michel Cahen is the leading scholar of all things Mozambican and has enriched our knowledge of Mozambique's present and past in numerous publications. It is a considerable honour that he has devoted so much attention to this Short History. His review is fair, thoughtful and based on an unrivalled knowledge of the country and its history. He is right that any author trying to summarise five hundred years of the history of any country faces severe problems. Few topics can be explored in any depth and many aspects of the culture and historical experience of the people have to be reduced to a passing reference or omitted altogether. So what is the purpose of a book that, by its very nature, must fail to do justice to its chosen topic? I have written at much greater length on Mozambique's history in a volume the size of a brick, so an abridged and updated account seemed to be important to enable those visiting Mozambique or doing business there to obtain some basic knowledge of the country in a format that can be read easily on the plane.

Michel Cahen has found eleven aspects of the book with which, to a greater or lesser extent, he has problems. Perhaps the most significant concerns the highly controversial and difficult topic of slavery. The first problem arises over the story of the chicunda, an ethnic group whose origin lies with people who over the centuries served the Portuguese of Zambesia in many different capacities, such as carriers, boatmen, hunters, fighters and traders. In my book I refer to the chicunda as 'clients' of the Portuguese but Michel Cahen thinks they should be considered slaves or slave soldiers similar to the Mamelukes of Egypt. This may seem a rather obscure subject for academics to disagree over, but it is more important than at first appears. To insist that the chicunda were slaves, and in particular slave soldiers, fits into the narrative of colonialism which sees Europeans, from the earliest time of their presence in Africa, as imposing slavery on the African populations, an essentially alien concept which deprived Africans not only of their freedom but of their personalities as free and autonomous individuals and of their traditional culture. This kind of slavery was not only cruel but was the archetype of all colonial exploitation. The comparison with the Mamelukes of Egypt recognises that European colonial slavery seldom involved the slaves becoming militarised. So another model of exploitation has to be found to explain this aspect of the life of the chicunda. 
These interpretations of the chicunda are premised on an idea that is apparently non-negotiable - that relations between Europeans and Africans have to be, by their very nature, exploitative. There can be no other perspective, so the task of the academic is confined to identifying exactly what type of exploitation is involved.

It is, of course, true that the Portuguese frequently use the terms escravo and cativo, to describe the Africans in their service but there is abundant contemporary evidence to make clear exactly what type of relationship these terms describe. The Portuguese who established themselves in Zambesia in the sixteenth and seventeenth centuries were very few in number and did not try to reproduce the sort of slave-owning society that existed in the Atlantic Islands or Brazil. Instead they adapted to the local social, economic and political practices they encountered. They found African communities that were organised in extended lineages which were accustomed to enlarge their productive capacity by acquiring women captives in warfare. These were incorporated into the lineage as wives. There is abundant contemporary evidence for this. There is also contemporary evidence for successful hunters or fighters attracting followers and establishing permanent communities or polities on a basis of clientship, as happened in many different parts of Africa. The Portuguese society that emerged in Zambesia followed closely these customs and constituted a creole society which mixed some European ideas and legal formulae (the laws that surrounded the award and inheritance of the prazos for example) with local practices of clientship and the expansion of communities through the acquisition of women. It is essential to understand that the environment and cultural context in which the chicunda communities were formed was specifically African, and that the Portuguese creoles had to become 'Africanised' to make their communities viable.

The chicunda were clients of the prazo senhors and senhoras not slaves in any of the ways that slavery was understood outside Africa. They were certainly not like the Mamelukes, except in so far as they acted as the fighting force of the prazos in addition to their other roles. The Mamelukes were usually recruited from Christian communities in the Balkans or Georgia. They were forcibly converted to Islam and their status was not supposed to be inherited by any children they might have.

Michel Cahen also has a problem with the connection made in the book between the gradual end of the Indian Ocean slave trade and the expansion 
of commodity production in lowland Mozambique towards the end of the nineteenth century. He is concerned that the impression is given that African farmers were somehow guilty of adopting a form of plantation slavery. There is no suggestion in the book that this is what occurred. However, there is an important connection made between the ending of the seaborne slave trade and events on the mainland, including the expansion of agricultural production. In the last quarter of the nineteenth century, as the seaborne slave trade from the Mozambique coast began to decline, the supply of slaves from the interior continued and slavers had to find new markets within Africa. There is evidence that some of the slaves reaching the coast were incorporated into the armies of local rulers - a militarisation of society that is quite apparent in the sources. The other obvious market was found in the demand for agricultural labour. In this case slaves would be incorporated into existing social formations as slave wives or junior lineages. It is doubtful whether the great expansion of agricultural production could have taken place without this supply of additional labour. This trend is apparent not only in the north but also in the south, where refugees from the destructive civil wars in Gaza arrived to seek refuge in coastal communities.

The study of the slave trade has often been focussed on the demand outside Africa and the experience of slaves sold overseas, with less attention paid to the dynamics of the trade and its markets within Africa, which should now be a key area of research.

\section{3}

\section{Warlords}

Michel Cahen also has a problem with my use of the term 'warlords' to describe various individuals (African, Muslim, Creole Portuguese and Indian) who carved out polities for themselves in nineteenth century Mozambique. I am aware that the term 'warlord' has been much discussed in the context of developments in post-independence Africa. However, I still think it is a useful term to describe how political power could be, and often was, achieved in Africa. Political and social change in pre-colonial Africa can be seen along a kind of spectrum with outlaws, bandits, successful fighters and hunters at one end, through settled communities that established themselves round powerful individuals, to traditional kingdoms with complex ties to spirit cults and lineages and through the exploitation of natural resources.

It is clear from the sources that successful warlords sometimes founded states that lasted beyond the lifetime of their founder and that they could acquire a kind of legitimacy through intermarriage with existing chiefly lineages 
and through the adoption of local customs (for example through relations with spirit cults).This was the case with some of the most famous nineteenth century prazo senhors like the Da Cruz and the Pereiras or like Livingstone's Makololo followers. Others fought their way to a power that proved transitory and disappeared as fast as it was established. In the recorded history of Mozambique, polities continually rose, flourished and disappeared. It was the 'little society' of the village and the lineage that provided stability and continuity.

\section{$4 \quad$ African Agency}

Michel Cahen also has a problem with the chapter which is focussed on African agency in the nineteenth century. He makes the point that, whatever else happened in the nineteenth century, Africans had no say, no agency, in the decisive events that led to the partition. This is, of course, true in general but it misses the point that the chapter was trying to make. Too often Africans have been seen by historians only as victims who have suffered the exploitation inflicted on them by the outside world, mostly by Europeans. Recently there has been some re-evaluation of the slave trade and of the role that Africans themselves played in the expansion of the trade and on determining the terms on which the trade was carried on. This re-evaluation needs to be taken further. Of course Africans were affected by the growth of international trade and the gradual spread of globalisation but, until the late nineteenth century, nonAfricans controlled very little of Africa's territory or population. How Africans responded to developments in the world outside Africa was largely under their control. The book discusses, as examples, the way Africans responded to the growth of commodity markets, the changing patterns of the slave trade and the onset of drought.

However, there is a wider discussion to be had. Over many centuries African culture has been resistant to the adoption and development of new technologies and to the wider uses of literacy beyond its role in religion. This aspect of Africa's history is often summed up in the observation that Africans never adopted the wheel - the water wheel, the spinning wheel, the potter's wheel, wheel barrows or wheeled vehicles. The consequences of this for Africa's economic and social development need to be seriously analysed. In the case of wheel-based technology, and in the case of literacy, Africans themselves have decided in what ways they should respond to developments in the non-African world, and these decisions have not been forced on them by outsiders. Africans have had agency. 
This remains a very serious issue. The state of Africa (including Mozambique) today is largely the result of decisions Africans themselves have made. The late Patrick Chabal was never tired of pointing out that Africa is rich and that its problems are due to the instrumentalisation by African elites of poverty, violence and underdevelopment. However, the narrative that sees Africa as powerless in the face of outside exploitation still dominates the discussions around debt, aid and poverty reduction, as well as discussions of Africa's long term development.

\section{5}

\section{Assimilation}

Michel Cahen is clear that the Portuguese policy of 'assimilation' was little more than a device for condemning the vast majority of the population Mozambique to forced labour by excluding them from citizenship rights. This, of course, is one aspect of 'assimilation'. Because so few Africans became assimilated, most of the population remained subject to the indigenato with its labour requirements. However, there is more to be said about 'assimilation', particularly in the light of policies that have been followed since independence.

Once the Portuguese had left Mozambique, Frelimo devised policies for the future of the country which placed all the emphasis on creating a new generation that would reject tradition and would adopt the scientific, rational ideas and behaviours that would characterise the 'new man'. In pursuit of this objective, traditional beliefs and institutions were to be abandoned - traditional marriage, traditional medicine, witchcraft beliefs, chieftaincies and traditional hierarchies. Even traditional villages were to be replaced by new collectivised communities. How much did these policies owe to 'assimilation' as defined by the colonial administration? To what extent were they really just a continuation of 'assimilation' under a different guise? There is a discussion to be had here.

There is a broader question, which is linked to the previous discussion of African reactions to developments in the outside world. The colonial governments decided that, for Africa to participate in the modern world, elites needed to be created who could operate in a world governed by literacy, technology, monetarised economies and bureaucratic regimes. These elites were to be found partly in those who were able to acquire a 'western' education and become 'assimilated' but also among chiefs selected to run local administrations and among successful farmers who would be brought into the market economy, who could form co-operatives and invest in agricultural improvement. Rightly or wrongly mass education was not seen as a practical way forward. 
There were many pathways these elites could follow to 'modernity', some of them in the hands of Africans, and Portuguese-style 'assimilation' was only one. After independence the route to 'modernity' through mass education was tried and has largely failed and African countries still pursue selective ways of encouraging the modernisation of their economies and institutions.

In his recent book on football in colonial Lourenço Marques, Nuno Domingos has a lot to say about 'assimilation'. The hurdles which had to be cleared before someone could become assimilado were so formidable that most people never tried and, anyway, they had no desire to separate themselves from their family and community which 'assimilation' would have entailed. But the idea and image of 'modernity' represented by 'assimilation' was nevertheless a very powerful influence on people's lives - not least in the world of football where local understandings of the game as it was played in the suburbs had to adjust to the demands of the game as played in the 'civilised' part of the city, in Portugal and in the wider world. What was true of football was true of scores of other occupations.

\title{
6 Conclusion
}

So, what was the book trying to achieve? It aimed to provide, in a manageable size, a coherent narrative of 'what happened' in the region that became Mozambique, but it was also intended to go much further. It may not have discussed issues at the level of ideology, as Michel Cahen clearly hoped, but it tried to look at the history of an African country with new perspectives. In particular, it tried to follow in the footsteps of Patrick Chabal in focussing on the way that Africans have been more in control of their own destinies than has sometimes been suggested. If countries like Mozambique are poor today, this is largely because of decisions made by Mozambicans themselves, just as it was Africans more broadly who made the decisions to reject the evolving technologies and literate culture of the non-African world and whose control over the supply of slaves meant that they were largely responsible for the dislocation and mayhem that occurred throughout the continent as a result of the trade.

\author{
Malyn Newitt \\ King's College London, United-Kingdom
}

